\title{
Reversible bilateral lower limb gangrene in a neonate at birth
}

\author{
Einas Elzubier Elmalik 지 , Mohammad A A Bayoumi
}

Neonatal Intensive Care Unit (NICU), Women's Wellness and Research Center (WWRC), Hamad Medical Corporation, Doha, Qatar

\section{Correspondence to}

Dr Mohammad A A Bayoumi; moh.abdelwahab@hotmail.com

Accepted 26 August 2021

Check for updates

(C) BMJ Publishing Group Limited 2021. No commercial re-use. See rights and permissions. Published by BMJ.

To cite: Elmalik EE,
Bayoumi MAA. BMJ Case
Rep 2021;14:e243959.
doi:10.1136/bcr-2021-
243959

\section{DESCRIPTION}

The case is of a male infant born preterm vaginally at 25 weeks. The mother was 31 years old, gravida 5 para 3 , and neither diabetic nor hypertensive. She developed preterm premature rupture of membranes 2 weeks before delivery. At that time, she was started on oral erythromycin $250 \mathrm{mg}$ tablet every 6 hours for 1 week. She also received 2 doses of betamethasone $12 \mathrm{mg}$ intramuscular every 24 hours for 1 week before delivery to enhance fetal lung maturation. She was seen in the antenatal clinic 1 week before the onset of labour. On the delivery day, she arrived at the emergency room (ER) fully dilated. After vaginal examination in the ER, the obstetric team palpated a cervical cerclage in place that was compressing the umbilical cord, leading to very faint and weak umbilical vessel pulses. Any intervention was not possible at that time as it was more important and urgent to save the infant. Moreover, the team did not want to risk another complication. The cerclage was therefore released just before the delivery.

The infant required positive pressure ventilation and endotracheal intubation, and surfactant administration in the delivery room. At birth, the infant was noted to have symmetrical blackish discolouration of the lower half of the body with a line of demarcation just below the umbilicus (figure 1). The distal pulsations were felt equally on both lower limbs.

The neonatal team considered several serious differential diagnoses including aortic thrombosis

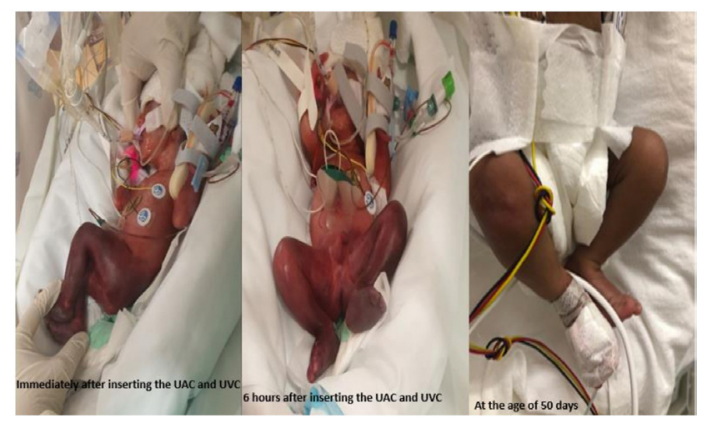

Figure 1 Symmetrical blackish discolouration of the lower half of the body with a line of demarcation just below the umbilicus. The patient's condition gradually improved from the age of 6 hours till complete resolution at the age of 3 days; the sensation function was completely preserved. The photo on the right side was taken at the age of 50 days after full feeding. The infant was on intravenous antibiotics for presumed sepsis with a healthy peripheral intravenous line on the dorsum of the right foot.

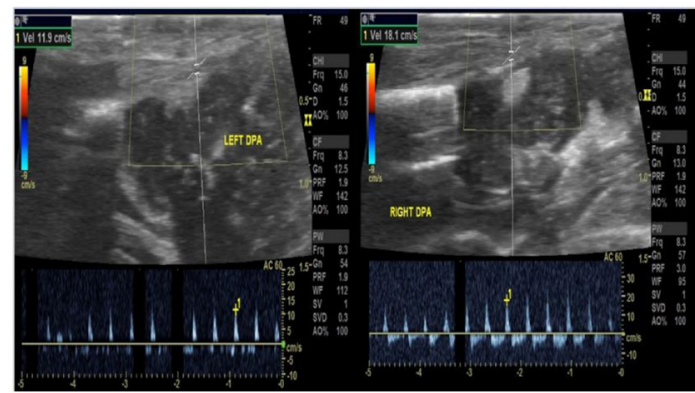

Figure 2 Doppler ultrasound of the dorsalis pedis artery on both sides. The artery shows a patent flow with no obvious intraluminal thrombus or stenosis. The available spectral flow pattern appears unremarkable and the peak systolic velocity is within the normal range.

or embolism, umbilical arterial thrombosis or embolism, umbilical venous thrombosis, distal aortic or femoral arterial stenosis, septic thrombosis or embolism and congenital hypercoagulable states. ${ }^{1}$

To determine the exact diagnosis, urgent lower limb Doppler ultrasound was requested. Interestingly, the ultrasound result was deemed normal by different experts in the first few hours of life (figure 2). Sepsis workup, including blood culture, was done at birth and it came back negative. Congenital thrombophilia and hypercoagulable states were excluded based on normal levels of protein $\mathrm{C}$, protein $\mathrm{S}$ and Factor $\mathrm{V}$ Leiden in the infant's blood after birth. Head, renovascular and abdominal ultrasound studies did not show any evidence of vascular anomalies, thrombosis, or tortuosity.

A therapeutic dilemma was raised when the infant needed umbilical arterial catheterisation (UAC) and umbilical venous catheterisation (UVC). Based on the equal and strong distal pulsations in both lower limbs as well as the Doppler ultrasound findings, the team agreed to insert the umbilical catheters with very close monitoring. UAC and UVC insertions were clinically mandated despite the potential risk of compromising limb perfusion. UAC and UVC were inserted successfully and kept in an optimal position. Close follow-up showed gradual improvement in the colour of the lower half of the body which started at the age of 6 hours till complete resolution on the third day of life.

As a final diagnostic aetiology, the neonatal team labelled this patient as a reversible bilateral lower limb gangrene due to umbilical cord compression by the cervical cerclage.

This is a very rare presentation of reversible lower limb gangrene at birth. ${ }^{2-4}$ Unusual decisions 
in critical situations are sometimes needed in the neonatal intensive care unit.

\section{Learning points}

Multidisciplinary team discussion and management with proper documentation and family counselling are the cornerstones of promoting safety in neonatal intensive care units.

- Critical thinking and unusual decisions in critical situations are sometimes needed in neonatal practice.

Acknowledgements The authors gratefully thank all the obstetricians, neonatologists, nurses and respiratory therapists who provided advanced medical care to this patient and his family. Special thanks to the parents who agreed to publish this case report and enrich the literature with its findings. Any errors are our own and should not tarnish the reputations of these esteemed persons.

Contributors EEE provided the idea for the article and was the clinician responsible for the patient, captured the images and helped in the revision of the article. MAAB gave the idea for the article, helped in the literature review, obtained the consent, writing the article and editing of images.

Funding The authors have not declared a specific grant for this research from any funding agency in the public, commercial or not-for-profit sectors.

Competing interests None declared.

Patient consent for publication Obtained.

Provenance and peer review Not commissioned; externally peer reviewed.

\section{ORCID iDs}

Einas Elzubier Elmalik http://orcid.org/0000-0003-2518-8161

Mohammad A A Bayoumi http://orcid.org/0000-0002-2627-4806

\section{REFERENCES}

1 Kumar A, Ramachandran S, Swain P, et al. Dual mutation (MTHFR A1298C with PAl (4G) mutation) manifesting with bilateral lower limb gangrene in a neonate. BMJ Case Rep 2021;14:e237340.

2 Strobelt N, Mariani E, Locatelli A, et al. Threatened premature delivery with prolased amniotic sac leading to neonatal limb gangrene. Acta Obstet Gynecol Scand 2000;79:805-6.

3 Turnpenny PD, Stahl S, Bowers D, et al. Peripheral ischaemia and gangrene presenting at birth. Eur J Pediatr 1992;151:550-4.

4 Lenzer J, Dolamore M. Reversible gangrene. J Fam Pract 1994;39:116-8.

Copyright 2021 BMJ Publishing Group. All rights reserved. For permission to reuse any of this content visit https://www.bmj.com/company/products-services/rights-and-licensing/permissions/

BMJ Case Report Fellows may re-use this article for personal use and teaching without any further permission.

Become a Fellow of BMJ Case Reports today and you can:

- Submit as many cases as you like

- Enjoy fast sympathetic peer review and rapid publication of accepted articles

- Access all the published articles

- Re-use any of the published material for personal use and teaching without further permission

Customer Service

If you have any further queries about your subscription, please contact our customer services team on +44 (0) 2071111105 or via email at support@bmj.com.

Visit casereports.bmj.com for more articles like this and to become a Fellow 